\title{
Pracownicy książki w Akademii Połockiej (1812-1820)
}

Mimo kasaty zakonu jezuickiego (1773) i kolejnych rozbiorów Rzeczpospolitej (1772-1795) szkoły jezuickie na Kresach - na Białej Rusi, kontynuowały swą pracę edukacyjną, duszpasterską i kulturalną z troską o zachowanie utraconej polskości i utrzymanie europejskiego charakteru. Szkoły te podporządkowano wyższemu kolegium w Połocku, które w roku 1812 zyskało status Akademii, działającej do momentu likwidacji tych placówek w marcu 1820 roku' 1 .

Fenomen połockiej placówki wynikał nie tylko z długiego trwania (1580-1820), lecz nade wszystko z jej międzynarodowego charakteru. Proces europeizacji zainicjowały od roku 1780 liczne przyjazdy uczonych jezuitów ze skasowanego już zakonu do odległego, kresowego Połocka². Była to wówczas jedyna w Europie działająca placówka zakonu SI. Przybysze przywozili swą wiedzę naukową, talenty i umiejętności oraz zbiory naukowe, instrumenty i cenne księgi. Wwożone księgozbiory wzbogacały zasoby biblioteki kolegium (wkrótce Akademii) i szkół jej podporządkowanych ${ }^{3}$. Coraz szerszy obszar panowania książki powiększały wielonakładowe połockie edycje dzieł naukowych i literackich, podręczników,

* Prof. zw. dr hab., profesor emerytowana, Uniwersytet Gdański, Wydział Filologiczny, Katedra Historii Literatury, ul. Wita Stwosza 55, 80-952 Gdańsk; e-mail: prof-ir-kad@wp.pl

${ }^{1}$ Powstanie i rozwój Akademii Połockiej przedstawia szerzej monografia I. Kadulskiej, Akademia Połocka - ośrodek kultury na Kresach (1812-1820), Wydawnictwo Uniwersytetu Gdańskiego, Gdańsk 2004. Artykuł nawiązuje do tej monografii.

${ }^{2} \mathrm{~W}$ Europie wzrost zainteresowania ośrodkiem połockim wynikał z ogłoszonej w 1780 roku decyzji Piusa VI o utworzeniu nowicjatu w Połocku. Otwierało to możliwość dalszego trwania i rozwoju zakonu. Por. Encyklopedia wiedzy o jezuitach na ziemiach Polski i Litwy 1564-1995, oprac. Ludwik Grzebień SJ przy współpracy Zespołu jezuitów, Wydział Filozoficzny Towarzystwa Jezusowego, Instytut Kultury Religijnej, Wydawnictwo WAM, Kraków 1996, s. 542-543, hasło: Połock.

${ }^{3}$ Por. B. Breżgo, Losy bibliotek jezuickich kolegiów w Połocku i Witebsku, „Przegląd Powszechny" 1926, t. 169, z. 1-3; L. Grzebień, Biblioteka jezuitów w Połocku na przełomie XVIII i XIX wieku, w: Gistoryja i archeologija Połacka i Połackoj zjamli, Nacyjanalny Połacki Gistoryka - Kulturny Muziej - Zapaviednik, Połack 2003, s. 59-63; I. Kadulska, Dzieje zbiorów bibliotecznych Akademii Połockiej na Kresach Wschodnich (1812-1820), „Rocznik Gdański” 2001, t. 61, z. 2, s. 71-92. 
słowników, książek o charakterze religijnym i innych ${ }^{4}$. Do świata książki należeli jej czytający użytkownicy - profesorowie, studenci, rzesze szlachty i wierni użytkownicy modlitewników, przewodników moralnych etc. W tej grupie mieszczą się także autorzy - tłumacze i twórcy dzieł, cenzorzy wznowień i pierwodruków, bibliotekarze - opiekunowie zbiorów bibliotecznych i muzealnych, księgarze zatrudnieni w akademickiej księgarni i nade wszystko pracownicy książki - mistrzowie czarnej sztuki drukarskiej.

Drukarze pojawili się w połockim kolegium z chwilą uruchomienia typografii w 1787 roku w czasie pełnienia funkcji rektora przez Franciszka Ksawerego Kareu. W początkowym okresie zarządzał nią Bazyli Szyrkiewicz. Jego pobyt w zakonie i ośrodku połockim (1785-1800) wypełniała praca w drukarni, rozpoczęta w 1788 roku pod kierunkiem pierwszego prefekta Macieja Rakiety5.

Erygowanie drukarni potwierdzało rozwój kolegium połockiego i było znakiem prestiżu. Ówczesny kronikarz Białoruskiej Prowincji zakonu Nikodem Muśnicki w części drugiej swej Historiae Societatis Iesu Rossiacae tak opisuje ten fakt:

\begin{abstract}
Aby kolegia mogły lepiej rozwijać studia humanistyczne, utrudnione zwłaszcza wprowadzeniem przeszkód w komunikowaniu się z prowincjami położonymi poza granicami Imperium Rosyjskiego i aby nie odczuwać braku książek potrzebnych najbardziej dla uczniów (studentów) otwarto w roku 1787 drukarnię w Kolegium Połockim. Stało się to z wielkim pożytkiem zarówno dla jezuitów jak i dla osób spoza naszego Zakonu. Dzięki wysokim nakładom finansowym ze strony Kolegium - nawet z odległych miejsc i za wygórowaną cenę sprowadzono czcionki i wzory form literowych w ilości wystarczającej do drukowania w różnych językach. Naturalnie sprowadzono także wszelki sprzęt i narzędzia potrzebne do zrealizowania tego celu.

To wszystko czyniono rozważnie, bowiem bardzo brakowało książek, którymi normalnie posługujemy się w naszych szkołach. [...] Inaczej nie można było zaradzić tej potrzebie, zwłaszcza że z roku na rok powiększała się liczba uczniów .
\end{abstract}

${ }^{4}$ Problem ten ilustruje Spis książek połockiej drukarni akademickiej zamieszczony w Aneksie I. monografii: I. Kadulska, Akademia Połocka ..., s. 207-225.

${ }^{5}$ W. Kaczorowski, R. Sękowski, Drukarnia połocka w latach 1787-1820. Problemy badawcze i próba odtworzenia produkcji wydawniczej, w: Jezuicka Ars Historica. Prace ofiarowane Ksiedzu Profesorowi Ludwikowi Grzebieniowi SJ, Wydawnictwo WAM, Wyższa Szkoła Filozoficzno-Pedagogiczna „Ignatianum”, Kraków 2001, s. 230; Encyklopedia wiedzy o jezuitach..., s. 527.

${ }^{6}$ N. Muśnicki, Historiae Societatis Jesu Rossiacae, conservatae in Alba Russiae et propagatae. Pars secunda: Historiae Alba Russiae Societatis Jesu. Rkps Archiwum Prowincji Polski Południowej Towarzystwa Jezusowego, Kraków (ATJKr. - sygn. 614), s. 9. Przekł. cyt. fragm. W. Gramatowski SJ. 
Drukarnia połockiego kolegium zyskała status typografii akademickiej z chwilą wymienienia jej w paragrafie 20. carskiego Przywileju powołującego Akademię Połocką:

Połocka jezuicka drukarnia bezpośrednio zostaje pod dozorem tejże Akademii. Cenzurę ksiąg w niej drukujących się powierza się trzem uczonym osobom z tegoż Zgromadzenia, znajomym ze swoich talentów?

Ustanowiony Przywilejem Komitet Cenzury oceniał i aprobował publikację tekstów pod kątem ich zgodności ze stanowiskiem Zgromadzenia. Zasada własnej wewnętrznej oceny druków (w tym także podręczników) generowała spory z Uniwersytetem Wileńskim, skąd kierowano skargi do Ministerstwa Oświecenia Publicznego w kwestiach kompetencyjnych ${ }^{8}$. Uczelnia Wileńska dążyła do zachowania prawa cenzurowania połockich druków.

Połocki Komitet Cenzury jako jednostka kolegialna składał się z trzech profesorów Akademii, którym towarzyszył sekretarz ${ }^{9}$. Działalność Komitetu regulował wewnętrzny Statut napisany przez generała jezuitów Tadeusza Brzozowskiego ${ }^{10}$. Cenzurą objęto nie tylko pierwodruki i wznowienia, ale także repertuar teatralny, zbiory przywożonych ksiąg i obrazów oraz eksponaty i kolekcje muzeum akademickiego. Nad całością tych prac czuwał sekretarz - czwarty członek Komitetu Cenzury, przechowujący pieczęć i prowadzący kancelarię. Sekretarz prowadził rejestry nadsyłanych dzieł, sporządzał wykazy decyzji Komitetu, pozostawał w kontakcie z drukarnią, gdzie sprawdzał etapy druku. On także zawiadamiał autora o konieczności wniesienia poprawek. Nie miał jednak uprawnień do wydawania tekstów autorom. Co miesiąc sporządzał dla rektora raport rejestrujący przyjęte dzieła i podjęte decyzje. Ostatecznym odbiorcą raportu był generał zakonu.

Obowiązkiem każdego cenzora było dokładne przeczytanie całego tekstu. Potwierdzano to zapisem słowa: przejrzałem $\mathrm{u}$ dołu strony wraz z pełnym podpisem. Cenzor redagował też formułę zezwolenia drukowaną na odwrocie karty tytułowej. Często wskazywał tu odbiorców egzemplarzy obowiązkowych. Rozbudowaną formułę Imprimatur zastępowano niekiedy lakonicznym zwrotem: „Wolno drukować”. Dopełnieniem drukowanego zezwolenia było imię i nazwisko cenzora, opa-

${ }^{7}$ Akt powołania Akademii podano w całości w: I. Kadulska, Akademia Połocka ..., s. 34-35.

${ }^{8}$ Pisma w tej sprawie przekazywane przez Uniwersytet Wileński do Kuratorii ks. Adama Jerzego Czartoryskiego i do Ministerstwa Oświecenia Publicznego znajdują się między innymi w: Vilniaus Universiteto Biblioteka (VUB) Wilno, Dział Rękopisów, sygn. F 2 KC - 28.

${ }^{9}$ Skład Komitetu Cenzury podawano do wiadomości w drukach o szerokim zasięgu. Por. Kalendarz na Rok Pański 1815 Akademii Połockiej Towarzystwa Jezusowego Akademickiej Drukarni. Egz. Biblioteki Czartoryskich K. 429. I. W tymże 1815 roku w skład Komitetu Cenzury wchodzili profesorowie Dezydery Richardot, Józef Cytowicz, Michał Leśniewski i sekretarz Klemens Piotrowski.

${ }^{10}$ I. Kadulska, Akademia Połocka..., s. 109. 
trzone jego stopniem naukowym oraz dokładną datą i miejscem wydania zgody. Decyzja odmowna skutkowała okólnym zawiadomieniem innych uniwersytetów i oznaczała całkowite oddalenie tekstu.

Oceniony i zaakceptowany rękopis sekretarz kierował do drukarni mieszczącej się w oficynie przylegającej do zespołu budynków akademickich ${ }^{11}$. Drukarnia zajmowała siedem pomieszczeń na parterze oficyny. Kolejność ich przeznaczenia i rodzaj wyposażenia wynikał z etapów powstawania książki. Tu dodajmy: na piętrze nad drukarnią mieściły się pomieszczenia teatru.

W zachowanej dokumentacji dokładnie wskazano prace wykonywane w poszczególnych „stancjach” drukarni; zasygnalizowano też przystosowanie do ustawiania sprzętów i maszyn:

W pierwszej z tych [stancji - przyp. I.K.] jest presernia; ma cztery okna, piec do połowy ceglany, od połowy kaflany; podłogi część drewniana, reszta z cegieł ${ }^{12}$.

Równie dużym pomieszczeniem o czterech oknach była sala druga. Tu mieściła się zecernia. Do stancji mniejszych - o dwóch oknach, należały następne: introligatornia, mieszkanie dozorcy drukarni oraz gisernia, czyli warsztat odlewniczy. Kolejne, szóste i siódme pomieszczenia były najmniejsze, każde wyposażone w jedno okno. Była to stancja chłopców drukarskich oraz magazyn drewnianych instrumentów drukarskich.

W oficynie drukarni znajdowały się także magazyny księgarskie jak i sama księgarnia. Dodatkowo funkcję magazynu pełniły też przestronne korytarze, gdzie składowano wielkie zapasy papieru różnej struktury, formatu i koloru. Były one przygotowane do druku i do opraw ${ }^{13}$. Zachowane $\mathrm{w}$ archiwach spisy rekwizycyjne pozwalają dokładnie zrekonstruować wyposażenie pomieszczeń drukarni w maszyny i sprzęty, informują o ich stanie technicznym i przydatności.

Pracą drukarni kierował prefekt przy pomocy trzech lub czterech koadiutorów mających pewne praktyczne przygotowanie. Funkcja prefekta drukarni, nazywanego też $\mathrm{w}$ dokumentacji prezesem typografii, nie była stałym zadaniem i pełniono ją obok innych, takich jak obowiązki wykładowcy, kaznodziei, bibliotekarza. Bezpośrednie prace drukarskie wykonywali pomocnicy - koadiutorzy; w hierarchii zakonnej najczęściej byli to bracia zakonni; wśród nich Alojzy Lenkiewcz, Jan Korsak, Antoni Sokołowski, Adam Michałowski, Jan Leszczyński,

${ }^{11}$ Opisy i inwentarze Kolegium Połockiego skreślone w styczniu 1820 roku. [Z oryginatu przepisat Tomasz Wall, Kraków 1907], rkps ATJKr 1326; Por. też: Akta wizyty kolegiów i rezydencji Zakonu Jezuickiego, najdujących się w Archidiecezji Mohylewskiej, podane za rok 1818, Nacjanalny Historyčny Archiv Biełarusi (NHAB) w Mińsku. Fond 1781, rkps 26, 1398.

${ }^{12}$ Akta wizyty kolegiów i rezydencji, Rkps NHAB, Mińsk, F 1781. 26, 1398, k. 11 v - 12.

${ }^{13}$ Szczegółowy opis zapasów i specyfikację papieru przygotowanego do druku (1073 ryzy) podaje zarówno inwentarz NHAB F 1781. 26, 1398, jak i Rkps Archivum Romanum Societatis Iesu, Rzym (ARSI). Collezione Gaillard sch. 34 Russia No 6, f. 382. 
Maciej Drykszew. Poziom ich praktycznych kwalifikacji nie jest dziś bliżej znany. O ich fachowości świadczą jednak osiągnięcia połockiej oficyny, liczba druków, ich kształt edytorski oraz wysokość i zróżnicowanie nakładów.

Pierwszym bezpośrednim zwierzchnikiem połockiej drukarni był, wspomniany już, Bazyli Szyrkiewicz, uważany za organizatora drukarni ${ }^{14}$. Obowiązki zarządzającego, a później drukarza wykonywał przez nieomal cały czas swego niedługiego pobytu w Połocku i obecności w zakonie (do roku 1800) ${ }^{15}$. Wśród następców na stanowisku prefekta typografii na uwagę zasługuje Tadeusz Brzozowski - wybitny jezuita, skierowany tu w początkach bytności w Połocku (1797-1805). W tym też czasie był cenionym kaznodzieją, wykładowcą języków obcych i sekretarzem zakonu $^{16}$. Wybrany w 1805 roku do pełnienia funkcji generała zakonu jezuitów, podjął starania o powołanie Akademii Połockiej. Podjęcie nowych zadań wiązało się z koniecznością przekazania niektórych jego obowiązków konfratrom. Zarządzanie drukarnią przejął Alojzy Lenkiewicz, jako dotychczasowy asystent i pomocnik.

Jednak z chwilą przybycia do Połocka Hieronima Haraburdy (luty 1806 roku) nastąpiła zmiana na tym stanowisku. Objął je właśnie ów przybysz - jako wykwalifikowany drukarz. Haraburda wcześniej zdobył cenne umiejętności drukarskie w oficynach w Warszawie i Nieświeżu ${ }^{17}$. W Połocku pełnił swą funkcję z przerwami w latach 1806-1815 i w miarę coraz słabszego zdrowia korzystał z pracy pomocnika - Jana Korsaka. Haraburda - najstarszy zakonnik w Połocku, mimo słabnącego wzroku przyczynił się do wzrostu osiągnięć drukarni. Otoczony wielką serdecznością studiującej tu młodzieży, był adresatem okolicznościowej poezji studenckiej. Stan zdrowia nie pozwolił mu na wyjazd z konfratrami po likwidacji Akademii. Pozostał na Białorusi pod opieką bazylianów w klasztorze w Czereji.

Prefekci zarządzający drukarnią zmieniali się co kilka lat, zgodnie z obowiązującymi przepisami. W ostatnich dwóch latach (1818-1820) funkcję tę pełnił Wincenty Żołądź - doktor teologii, zarządzający uczelnianym Wydziałem Języków. Jako kierownik drukarni przyczynił się do wzrostu liczby edycji podręczników i słowników językowych. Wśród nich zwracają uwagę wznowienia pism Piotra Skargi, Torquata Tassa w przekładzie Piotra Kochanowskiego, czy też kilkutysięczne nakłady podręczników do nauki języka polskiego ${ }^{18}$. Zarówno praca drukarni, jak i jego funkcja zostały ukazem cesarskim gwałtownie przerwane w marcu 1820 roku. Mimo aktu nakazującego natychmiastową likwidację uczel-

${ }^{14}$ W. Kaczorowski, R. Sękowski, dz. cyt., s. 230. Wskazany wyżej wykaz prefektów podaje Encyklopedia wiedzy o jezuitach..., s. 526.

${ }^{15}$ Encyklopedia wiedzy o jezuitach..., s. 672.

${ }^{16}$ Tamże, s. 73-74.

${ }^{17}$ W. Kaczorowski, R. Sękowski, dz. cyt., s. 231; Encyklopedia wiedzy o jezuitach..., s. 209-210.

${ }^{18}$ Oferta połockiej drukarni i księgarni akademickiej zostały przedstawione w szczegółowym wykazie w: I. Kadulska, Akademia Połocka..., s. 88-121. 
ni i ekspulsję jezuitów, prefekt drukarni był zobowiązany do pozostania i udziału w spisywaniu wyposażenia jednostek, za które odpowiada $1^{19}$.

Rekwizycję prowadził wysłannik ministra oświecenia - Kirył Kanarowski-Sochowicz, który kolejne protokoły przekazywał ministrowi Aleksandrowi Golicynowi i witebskiemu gubernatorowi. W pierwotnym założeniu przygotowywano drukarnię do przejęcia przez księży pijarów jako jej nowych właścicieli. Sporządzenie dokumentacji rekwizycyjnej zajęło kilka miesięcy i wymagało stałego uczestnictwa prefekta w pracach carskiej komisji. Ksiądz Żołądź podpisywał każdą stronę spisu likwidacyjnego swym imieniem i nazwiskiem. Spisy te, z pewnymi modyfikacjami zachowały się do dziś w zbiorach archiwów ${ }^{20}$.

Inwentarz „Z natury” potwierdzał rzeczywiste zasoby drukarni i magazynów, ale - jak wspomniano - wkrótce $\mathrm{w}$ dokumentach pojawiły się rozbieżności i ubytki.

Dojmująca sytuacja lustracyjna została zakończona 21 czerwca 1820 roku; ksiądz Wincenty Żołądź złożył podpis na protokole końcowym. Całościowy spis przedstawił wyposażenie dobrej drukarni początków XIX wieku i ujawnił jej typograficzne możliwości.

Sprzęty i maszyny wymienione i spisane przez komisję zostały zatrzymane „W samym środku pracy”. I tak w preserni cztery wielkie prasy były zajęte ułożonym drukiem; dwie mniejsze przygotowano do tłoczenia ilustracji. Piąta z wielkich pras - największa i najnowocześniejsza - nie została jeszcze uruchomiona. Jej obsługa była skomplikowana i wymagała fachowego przygotowania. Z tego też powodu pijarzy, którzy przejęli drukarnię, jeszcze po dziesięciu latach nie potrafili jej uruchomić. Proces druku wymagał także korzystania z szeregu obecnych w preserni sprzętów, na przykład ram do pras, urządzeń do przygotowania i rozcierania farby, blach „sztycharskich” o różnorakiej tematyce, stołów i sznurów do przeszywania papieru i innych.

W spisie sprzętów zecerni zwraca uwagę piec do palenia sadzy angielskiej, który umożliwiał bezpośrednią produkcję pigmentu do farby drukarskiej.

W introligatorni zaś zwrócono uwagę na trzy wielkie stoły introligatorskie do przygotowywania opraw, sześć pras introligatorskich oraz szereg sprzętów pomocniczych, na przykład scabellum, poduszkę do cięcia złota, sznury do suszenia papieru.

Pomieszczenie giserni zastawione było regałami i kasztami z bogatym zestawem (sześć i pół tony) różnorodnych czcionek. Opisano je w odrębnym raporcie lustratora Kiryła Sochowicza. Czcionki zostały zważone i spisane z podziałem

${ }^{19}$ Komisją lustracyjną spisującą bibliotekę i drukarnię Akademii Połockiej kierował Kirył Kanarowski-Sochowicz dyrektor gimnazjum w Witebsku, który włączył do prac komisji ludzi zaufanych spośród miejscowej inteligencji. Rkps ARSI Rzym Coll. Gaillard, sch. 34, No 6, f. 325, f. 351.

${ }^{20}$ Spisy biblioteczne i księgarskie wysyłane rozstawną pocztą do Petersburga i Witebska zachowały się dziś w: ARSI Rzym, NHAB Mińsk, VUB Wilno, ATJKr i CGIA (Centralne Narodowe Historyczne Archivum Rosji) Sankt Petersburg. 
na „litery łacińskie, polskie, rosyjskie, niemieckie, greckie, żydowskie”21. Tłoczono też druki francuskie, łotewskie i włoskie oparte na czcionkach łacińskich. Czcionki były także uporządkowane ze względu na obraz wizualny i ich wysokość. Wyodrębniono materiał zecerski do składów specjalnych - znaki matematyczne, chemiczne, czy znaki do składu nutowego, a także ornamenty drukarskie, ozdobne inicjały, winietki i finały etc. Prezentacją możliwości drukarskich tej oficyny była ulotka reklamowa przygotowana przez księży pijarów, tuż po przejęciu jezuickich zasobów ${ }^{22}$.

W tych właśnie pomieszczeniach drukarni, posługując się specjalistycznymi sprzętami, pracowali koadiutorzy i chłopcy drukarscy; kierownictwo sprawował prezes, a dozór bezpośredni nad sprzętami i wyposażeniem powierzono dozorcy. Najliczniejszą grupą pracowników książki byli chłopcy drukarscy, dla których przeznaczono początkowo skromną, niewielką izdebkę (dla pojedynczego pracownika). Rozwój drukarni spowodował powiększenie się tej grupy. W roku 1818 było ich już dwunastu, w roku następnym przyjęto kolejnego chłopca. Izba dla chłopców drukarskich była już dla nich za mała, korzystali więc z izby w konwikcie oraz ,stołu i odzienia klasztornego”.

Zawodowa edukacja chłopców drukarskich była częścią jezuickiego szkolenia młodzieży z okolicznych ubogich rodzin. W Połocku, w ramach kształcenia kadr rzemieślniczych, przysposabiano chłopców do zawodu piekarza, ogrodnika, pomocnika aptekarza, krawca, szewca, stolarza, rymarza, cieśli, młynarza i innych. Kształcenie drukarzy przyniosło nadspodziewanie dobre rezultaty. Po wyjeździe jezuitów z Rosji byli oni cenionymi i poszukiwanymi specjalistami. O ich przekazanie prosił kilkakrotnie Ekscelencję Pana Ministra Oświecenia Publicznego witebski gubernator.

Osiągnięcia drukarni Akademii Połockiej poświadczały drukowane tam serie wydawnicze (na przykład dzieła J. Kochanowskiego, I. Krasickiego, N. Muśnickiego i A. Naruszewicza), edycje ekskluzywne (dzieła P. Skargi), popularne śpiewniki, modlitewniki, przewodniki religijne wydawane w kilku wersjach cenowych (na przykład Złote ołtarzyki), przewodniki misyjne, słowniki wielojęzyczne, podręczniki, wznowienia klasyki literatury polskiej i obcej. Nakłady znane są dziś w przybliżeniu, natomiast zachowana informacja o cenach jest wiarygodna i konkretna $^{23}$. Ofertę drukarni przedstawiano każdego roku w Katalogu książek połoc-

${ }^{21}$ Rzadkim rodzajem spisu jest wykaz czcionek i znaków drukarskich, które komisja spisywała i ważyła w giserni, zecerni i innych pomieszczeniach drukarni. Oprócz czcionek sprowadzanych z Francji, zakupionych w drukarni Józefa Zawadzkiego odlewano także własne litery - „,połockie". Wykaz czcionek w: I. Kadulska, Akademia Połocka..., s. 226-228.

${ }^{22}$ Por. Próba druków połockiej typografii, po przekazaniu jej pijarom (1823 rok). Ilustracja po s. $96 \mathrm{w}$ : tamże.

${ }^{23}$ Komisja, spisując w systemie tabelarycznym wszystkie druki zastane w księgarni, drukarni i magazynach, podawała także cenę każdej pozycji według katalogu drukarni. Por. tamże, s. 207-218. 
kiej typografi; podawano tu informację w języku polskim i rosyjskim o tytułach, cenach i nakładach. Nie zachował się żaden egzemplarz, do rzadkości należą również ocalałe połockie druki. Zatem działalność i produkcję wydawniczą połockiej drukarni akademickiej przedstawiamy głównie w oparciu o spisy rekwizycyjne przechowywane w archiwach, pamiętając o zachowanych w niektórych bibliotekach połockich drukach w błękitnych kartonowych oprawach.

\section{Bibliografia}

\section{Podmiotowa}

Akta wizyty kolegiów i rezydencji Zakonu Jezuickiego, najdujących się w Archidiecezji Mohylewskiej, podane za rok 1818, Nacjanalny Historyčny Archiv Biełarusi (NHAB) w Mińsku. Fond 1781, rkps 26, 1398.

Akta wizyty kolegiów i rezydencji, Rkps NHAB, Mińsk, F 1781, rkps 26, 1398, k. 11 v - 12.

Kalendarz na Rok Pański 1815 Akademii Połockiej Towarzystwa Jezusowego Akademickiej Drukarni. Egz. Biblioteki Czartoryskich K. 429. I.

Komitet szkolny. Akta, raporty, korespondencje szkół etc. 8. Gub.Witebska. C. Połock. Księga z aktami zdawania biblioteki, kancelarii i gabinetów Akademii Połockiej z roku 1822. Vilniaus Universiteto Biblioteka, Wilno, rkps F 2 - KC - 608, k. 80-122.

Muśnicki Nikodem, Historiae Societatis Jesu Rossiacae, conservatae in Alba Russiae et propagatae. Pars secunda: Historiae Alba Russiae Societatis Jesu. Rkps Archiwum Prowincji Polski Południowej Towarzystwa Jezusowego, Kraków, (ATJKr) sygn. 614.

Opisy i inwentarze Kolegium Połockiego skreślone w styczniu 1820 roku. [Z oryginału przepisat Tomasz Wall, Kraków 1907], rkps ATJKr sygn. 1326.

\section{Przedmiotowa}

Breżgo Bolesław, Losy bibliotek jezuickich kolegiów w Połocku i Witebsku, „Przegląd Powszechny" 1926, t. 169, z. 1-3, s. 88-94.

Encyklopedia wiedzy o jezuitach na ziemiach Polski i Litwy 1564-1995, oprac. L. Grzebień SJ przy współpracy Zespołu jezuitów, Wydział Filozoficzny Towarzystwa Jezusowego, Instytut Kultury Religijnej, Wydawnictwo WAM, Kraków 1996, s. 542-543, hasło: Połock.

Grzebień Ludwik, Biblioteka jezuitów w Połocku na przełomie XVIII i XIX wieku, w: Gistoryja i archeologija Połacka i Połackoj zjamli, Nacyjanalny Połacki Gistoryka - Kulturny Muziej - Zapaviednik, Połack 2003, s. 59-63.

Kaczorowski Włodzimierz, Sękowski Roman, Drukarnia połocka w latach 1787-1820. Problemy badawcze i próba odtworzenia produkcji wydawniczej, w: Jezuicka Ars Historica. Prace ofiarowane Księdzu Profesorowi Ludwikowi Grzebieniowi SJ, Wydawnictwo WAM, Wyższa Szkoła Filozoficzno-Pedagogiczna „Ignatianum”, Kraków 2001, s. 219-244.

Kadulska Irena, Akademia Połocka - ośrodek kultury na Kresach (1812-1820), Wydawnictwo Uniwersytetu Gdańskiego, Gdańsk 2004.

Kadulska Irena, Dzieje zbiorów bibliotecznych Akademii Połockiej na Kresach Wschodnich (1812-1820). „Rocznik Gdański” 2001, t. 61, z. 2, s. 71-92. 


\section{Irena Kadulska}

Books-related employees at the Academy of Polotsk (1812-1820)

\section{(Summary)}

The paper presents activities of the printing house founded in 1787 at the Jesuit College in Polotsk. The printing house became an academic printing house in 1812; it ceased to exist at the time of the dissolution of the Academy.

The group of the most important printing house personnel, including the managing prefects and the employees directly associated with books - from the censors and the coadjutors to the printing house boys, is listed. Based on the existing inventory lists, their workshop, i.e. the printing equipment housed in all the printing house rooms, can be presented in detail, and their printing achievements, i.e. editions of the books stored in the warehouses and the academic bookshop, can be indicated.

Keywords: Academy; censorship; printing house; printers; printed matter; publishers' catalogues Słowa kluczowe: Akademia; cenzura; drukarnia; drukarze; druki; katalogi wydawnicze 